2000. Growth rate and potential climate record from a rhodolith using ${ }^{14} \mathrm{C}$ accelerator mass spectrometry. Limnol. Oceanogr. 45: 1773-1777.

Kalish, J. M. 1993. Pre- and post-bomb radiocarbon in fish otoliths. Earth Planet. Sci. Lett. 114: 549-554.

Milton, D. A., S. A. Short, M. F. O’Neill, and S. J. M. Blaber. 1995. Ageing of three species of tropical snapper (Lutjanidae) from the Gulf of Carpentaria, Australia, using radiometry and otolith counts. Fish. Bull. 93: 103-115.

MRAG AMERICAS, INC. 1997. Consolidated report on the peer review of red snapper (Lutjanus campechanus) research and management in the Gulf of Mexico. Report to the Office of Science and Technology, U.S. Department of Commerce. NOAA, NMFS.

Quay, P. D., B. Tilbrook, C. S. Wong. 1992. Oceanic uptake of fossil fuel $\mathrm{CO}_{2}$ : Carbon-13 evidence. Science. 256: 74-79.

RENDER, J. H. 1995. The life history of red snapper, Lutjanus campechanus, and its affinity for oil and gas platforms. Doctoral dissertation, Louisiana State Univ.
ShIRrIPA, M. J., AND K. M. Burns. 1997. Growth estimates for three species of reef fish in the eastern Gulf of Mexico. Bull. Mar. Sci. 61: 581-591.

- AND C. M. Legault. 1999. Status of the red snapper in the U. S. waters of the Gulf of Mexico: Updated through 1998. National Marine Fishery Service, Southeast Fisheries Science Center, Miami Laboratory, Contrib. MIA-99/00-75: 1-62.

Summerfelt, R. C., AND G. C. Hall. 1987. Age and growth of fish, 1st ed. Iowa State Univ. Press.

Stuiver, M., AND H. A. Polach. 1977. Discussion: Reporting of ${ }^{14} \mathrm{C}$ data. Radiocarbon. 19: 355-363.

Wilson, C. A., AND D. L. NiEland. In press. Age and growth of red snapper Lutjanus campechanus from the northern Gulf of Mexico off Louisiana. Fish. Bull. U. S.

Received: 6 December 2000

Accepted: 3 July 2001

Amended: 30 July 2001

\title{
Mesozooplankton grazing effect on primary production: A global comparative analysis in marine ecosystems
}

\begin{abstract}
A comparative analysis of the importance of mesozooplankton (200-20,000 $\mu \mathrm{m})$ as grazers of the phytoplanktonic primary production (PP) across a wide spectrum of marine ecosystems revealed mesozooplankton ingestion rates to increase nonlinearly with increasing PP. The slope of the log$\log$ relationship between ingestion rates and PP was significantly $<1$, indicating a decline of relative importance of mesozooplankton grazing with increasing PP. The effect of mesozooplankton on PP (as the percent PP consumed per day) is moderate in most of the studies (mode 6\%, mean 22.6\%) and decreases exponentially with increasing productivity. Contrary to the common assumption, the size barrier imposed by dominant picoautotrophs does not always result in a lower grazing pressure in unproductive communities (we consider here those with $\mathrm{PP}<250 \mathrm{mg} \mathrm{C} \mathrm{m}^{-2} \mathrm{~d}^{-1}$ ). Yet, the amount of phytoplanktonic carbon ingested per unit of mesozooplankton biomass is lower in unproductive than in moderate (250 to $1,000 \mathrm{mg} \mathrm{C}$ $\left.\mathrm{m}^{-2} \mathrm{~d}^{-1}\right)$ and highly productive communities $(>1,000 \mathrm{mg} \mathrm{C}$ $\mathrm{m}^{-2} \mathrm{~d}^{-1}$ ). This observation, together with the generally low values of daily biomass-specific ingestions, suggests that alternative food sources (e.g., protozoans) must represent an important component of mesozooplankton diet in unproductive ecosystems. The relationships obtained in the study yield an estimate of $5.5 \mathrm{Gt}$ phytoplanktonic $\mathrm{C}$ consumed per year in the global ocean, which represents $\sim 12 \%$ of the oceanic PP.
\end{abstract}

Traditional views on the flow of carbon in planktonic food webs have been revised to assign an important role to microbial food webs (Azam et al. 1983) and to consider nonlinear effects, such as feedback and trophic cascade, as important structural factors (Pace et al. 1998; Calbet and Landry 1999). Similarly, copepods are no longer considered to be the main consumers of the phytoplanktonic primary production (PP) (Tsuda et al. 1989; Bradford-Grieve et al. 1998; Calbet and Landry 1999; Sautour et al. 2000) and apart from algae a sizable portion of their daily ration is also composed of heterotrophic flagellates and ciliates (Tiselius 1989; Fessenden and Cowles 1994; Calbet et al. 2000). Yet, mesozooplankton remain important consumers of phytoplankton carbon, particularly in productive ecosystems, where the classic linear food chain still appears to be the main path of carbon transfer. In productive ecosystems, sedimentation and advection are also important mechanisms of PP loss (Baines et al. 1994; Wassmann 1998). In contrast, these carbon losses appear to be low in unproductive ecosystems, where the efficient recycling of nutrients and organic matter minimizes carbon export. This recycling appears to be maintained largely by bacteria and small $(<20$ $\mu \mathrm{m}$ ) protozoans (Azam et al. 1983; Sherr et al. 1988; Calbet et al. 2001). Moreover, picoplanktonic organisms, which are relatively unavailable to mesozooplankton predation are also responsible for an important proportion of the PP in these nutrient-poor systems (Agawin et al. 2000). As a result, mesozooplankton seem unlikely to efficiently exploit the primary production of unproductive ecosystems, except for some groups (e.g., tunicates and cladocerans), which may prey down to the picometer size fraction. Unfortunately, their abundance and effect have been traditionally neglected, and we lack knowledge on the relative importance of these groups in planktonic food webs (see review by Gorsky and Fenaux 1998).

Thus, the pattern depicted from the available information suggests an important removal of primary production by mesozooplankton in productive waters and a minor role in unproductive ecosystems. This view remains hypothetical and 
Table 1. Summary of the studies used in the data set with reference to the geographical area surveyed, the methodology employed, and the zooplanktonic groups considered. GC, gut content method; NPD, no pigment degradation losses considered; PD, pigment degradation losses considered; PDL, pigment degradation obtained from literature; MZ, mixed zooplankton considered; C, only copepods considered.

\begin{tabular}{|c|c|c|c|c|}
\hline Source & Zone surveyed & Method & Group & $\begin{array}{c}\text { No. of } \\
\text { measures }\end{array}$ \\
\hline Arinardi et al. 1990 & Banda Sea, Indonesia & GC, NPD & $\mathrm{C}$ & 3 \\
\hline Atkinson and Shreeve 1995 & Bellingshausen Sea & Incubation & $\mathrm{C}$ & 3 \\
\hline Baars and Fransz 1984 & North Sea & Incubation & $\mathrm{C}$ & 3 \\
\hline Barquero et al. 1998 & Atlantic Sea, NW Spain & GC, NPD & $\mathrm{C}$ & 6 \\
\hline Bradford-Grieve et al. 1998 & Subtropical convergence, S Africa & GC, NPD & $\mathrm{M}^{*}$ & 19 \\
\hline Conover and Mayzaud 1984 & Nova Scotia inlet & Incubation & $\mathrm{M}$ & 11 \\
\hline Dagg et al. 1982 & Bering Sea & Incubation & M & 9 \\
\hline Dam et al. 1993 & North Atlantic & $\mathrm{GC}, \mathrm{PD}$ & $\mathrm{C}$ & 14 \\
\hline Dam et al. 1995 & Central Pacific & GC, NPD & M & 18 \\
\hline Dubischar and Bathman 1997 & Southern Ocean, Atlantic sector & GC, NPD & M & 1 \\
\hline Froneman et al. 1997 & Lazarev Sea, Southern Ocean & GC, PD & M & 12 \\
\hline Froneman et al. 2000 & Southern Ocean, Atlantic sector & GC, PD & M & 16 \\
\hline González et al. 2000 & Northern Humboldt Current area & GC, NPD & M & 3 \\
\hline Gowen et al. 1999 & Western Irish Sea & $\mathrm{GC}, \mathrm{PD}$ & $\mathrm{C}$ & 9 \\
\hline Huskin 2001 & Atlantic Ocean & GC, NPD & $\mathrm{C}$ & 24 \\
\hline Landry et al. 1994 & Southern California Bight & GC, PD & M & 6 \\
\hline Morales et al. 1991 & NE Atlantic & GC, NPD & $\mathrm{C}$ & 18 \\
\hline Nielsen and Hansen 1995 & Disko Bay, West Greenland & GC, NPD & $\mathrm{C}$ & 6 \\
\hline Pakhomov and Perissinotto 1997 & Subtropical convergence, S. Africa & GC, PD & $\mathrm{M}$ & 10 \\
\hline Pakhomov et al. 1997 & South Georgia, Antarctica & GC, PDL & $\mathrm{M}^{*}$ & 6 \\
\hline Roman et al. 1993 & Sargasso Sea & Incubation & $\mathrm{M}$ & 2 \\
\hline Roman and Gauzens 1997 & Equatorial Pacific & Incubation & $\mathrm{C}$ & 2 \\
\hline Sautour et al. 1996 & Gironde estuary & GC, NPD & M & 4 \\
\hline Sautour et al. 2000 & Gironde estuary & GC, PDL & $\mathrm{C}$ & 8 \\
\hline Tiselius 1988 & Skagerrak and Kattegat, Baltic Sea & $\mathrm{GC}$ & $\mathrm{C}$ & 3 \\
\hline Ward et al. 1995 & South Georgia, Antarctica & Incubation & $\mathrm{C}$ & 2 \\
\hline Zhang et al. 1995 & Central tropical Pacific & GC, NPD & M & 25 \\
\hline
\end{tabular}

*Mesozooplankton dry weight converted to carbon using a factor of $40 \%$.

needs to be tested quantitatively. Here, I provide evidence of the increase in the mesozooplankton grazing pressure on primary producers with increasing productivity. I searched the literature for concurrent reports of primary production and mesozooplankton grazing in marine ecosystems. The resulting data set included 27 studies (Table 1) providing a total of 243 data points (i.e., paired observations on primary production and mesozooplankton community grazing), including coastal and open ocean ecosystems. Although this data set results from an exhaustive scrutiny of the literature, additional reports may have escaped the search. This data set encompasses a broad range of primary production (from 28 to $>4,000 \mathrm{mg} \mathrm{C} \mathrm{m}^{-2} \mathrm{~d}^{-1}$ ) and should provide an adequate test of the hypothesis posed.

Methods-The grazing estimates I used were measured in two ways: the gut pigment content method and clearance rates derived from incubations. Both have flaws. The gut content method may underestimate grazing rates due to pigment degradation within the gut (Kiørboe and Tiselius 1987; Dam and Peterson 1988; Mayzaud and Razouls 1992). Many of the reported estimates account for these losses, either through parallel experiments, or using literature values. Whenever no such correction had been attempted, a correction factor of $\times 1.5$ was applied to the published estimates (Kiørboe and Tiselius 1987; Dam and Peterson 1988; May- zaud and Razouls 1992). On the other hand, incubations can bias results through bottle artifacts or animal stress. Other methods based on physiological measurements, like respiration or egg production, were not considered in the study because they may overestimate the consumption of phytoplankton by assuming it is the unique source of carbon. Corrections for this problem can only be applied with knowledge of the proportion of autotrophic and heterotrophic food in the diet, which usually is not reported in the studies.

Data were divided into three intervals according to their

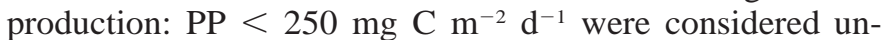
productive systems (22\% of the data points); $250 \leq \mathrm{PP} \leq$ $1,000 \mathrm{mg} \mathrm{C} \mathrm{m}^{-2} \mathrm{~d}^{-1}$ was considered moderately productive (50\%); PP $>1,000 \mathrm{mg} \mathrm{C} \mathrm{m}^{-2} \mathrm{~d}^{-1}$ was considered highly productive $(28 \%)$. This classification, although arbitrary, is coherent with an average value of PP for the entire open ocean of about $350 \mathrm{mg} \mathrm{C} \mathrm{m}^{-2} \mathrm{~d}^{-1}$ (Knauer 1993). Thus, ecosystems were considered to be unproductive whenever primary production was substantially below this mean value and highly productive whenever they far exceed it, as is observed in the most productive biogeochemical provinces of the ocean (Longhurst et al. 1995).

Data were log-transformed to stabilize variance and attain homoscedasticity. Because of the uncertainties associated with the grazing estimates and to prevent possible bias derived from combining estimates produced with different techniques, 
the results also have been presented by first grouping the estimates in bins of increasing primary production and then calculating the geometric mean to represent each bin in the regression (interval of 0.08 units on a log scale).

Results and discussion-Mesozooplankton grazing on phytoplankton ranged from nearly 0 to $1,772 \mathrm{mg} \mathrm{C} \mathrm{m}^{-2} \mathrm{~d}^{-1}$ and, as hypothesized, increased significantly $(P<0.001)$ with increasing primary production (Fig. 1). No significant differences were found between the different techniques used to estimate mesozooplankton grazing on PP (analysis of covariance [ANCOVA], $P=0.12$ ); consequently, data were grouped for statistical analysis. Mesozooplankton ingestion rates were lower than primary production (Wilcoxon signed rank test, $P<0.001$ ), with a slope of the log-log regression equation significantly $<1$ ( $t$-test, $P<0.001$ for both the raw data and the geometric means within bins). This indicates that the relationship is nonlinear, with the relative proportion of primary production removed by mesozooplankton grazing (i.e., the percentage of PP daily grazed) declining from unproductive to productive communities. The values ranged from null to almost $300 \%$ with a mean of $22.6 \%$. Removal of $<10 \%$ of PP occurred in $47 \%$ of the reports and of $<25 \% \mathrm{PP}$ in $73 \%$ of the data used. The percentage of PP consumed averaged $40.4 \% \pm 7.8$ (SE) for unproductive, $22.2 \% \pm 2.7$ for moderately productive, and $10.1 \% \pm 1.2$ for highly productive communities, thus confirming the existence of a negative relationship between the percentage of PP consumed and primary production.

The biomass-specific grazing rates, calculated from the studies where mesozooplankton biomass was provided, showed an important variability, but increased significantly with PP (Fig. 2, $P<0.001$ ). Hence, although the average daily consumption rates of mesozooplankton of unproductive systems represent only $5.9 \% \pm 0.01$ of the mesozooplankton body carbon, those of intermediate and productive ecosystems account for $19.9 \% \pm 0.04$ and $23.5 \% \pm 0.04$ of mesozooplankton carbon, respectively. Thus, both mesozooplankton ingestion rates and biomass-specific ingestion rates increase with increasing PP.

The low biomass-specific ingestion rates and the higher effect of mesozooplankton on PP (percent consumed daily) suggest food limitation of mesozooplankton in unproductive ecosystems. This is consistent with the higher biomass of mesozooplankton supported by a given autotroph biomass in unproductive systems (Alcaraz 1982; Gasol et al. 1997). However, phytoplankton is not the only food source zooplankton consume. Assuming a $25 \%$ gross growth efficiency for metazoan zooplankton (Straile 1997), the mesozooplankton production rates expected from the phytoplankton ingestion rates range between 0.015 and $0.06 \mathrm{~d}^{-1}$, which are below the range of values commonly found in planktonic marine systems (Huntley and Lopez 1992; Hirst and Lampitt 1998). Thus, even if food limitation exists, other food sources (e.g., protozoans) must provide a sizeable fraction of zooplanktonic daily rations (Tiselius 1989; Fessenden and Cowles 1994; Calbet et al. 2000). This heterotrophic contribution to mesozooplanktonic diet will be higher in unproductive communities, consistent with the tendency toward a decline in the relative contribution of planktonic hetero- trophs to community biomass with increasing PP (Gasol et al. 1997).

The results demonstrate a negative exponential relationship between mesozooplankton grazing and PP. Contrary to conventional wisdom, the size barrier imposed by the dominant pico-sized autotrophs does not always result in a low grazing pressure in unproductive communities. PP losses due to mesozooplankton grazing can be highly relevant in unproductive systems, although they are variable, ranging from almost a null effect to as much as the three times the total amount of the phytoplanktonic biomass produced. Whereas a large proportion of this PP in unproductive systems is due to picoplanktonic organisms $(=50 \%$, Agawin et al. 2000) and unavailable for most mesozooplanktonic groups, the rest of production may well be accessible. However, this does not completely explains the $<1$ slope found in the relationship between PP and mesozooplankton ingestion rates. Thus, mesozooplankton in some way also must be feeding on picoplanktonic PP. It seems quite unlikely that the grazing pressure on pico-sized organisms is due to copepods (Calbet et al. 2000), the most numerous group within zooplankton. On the other hand, other groups, like pelagic tunicates and certain cladocerans, are able to remove such small prey items (Fortier et al. 1994, Gorsky and Fenaux 1998). These groups are broadly distributed and present in most of the ecosystems and could have a proportionally higher effect on primary producers in unproductive regions. Even though the data presented in this study are not fully adequate to test this hypothesis, it is worth mentioning that to obtain the grazing estimates, the relationship between PP and mesozooplankton consumption depends on the groups considered. In studies contemplating only copepods as grazers (12 reports) the relationship between ingestion rates and PP is not significant in unproductive $(P=0.91)$ and moderately productive systems $(P=0.40)$, whereas it becomes significant $(R=0.65$, $P<0.001)$ for highly productive regions. For the rest of the studies, including not only copepods, but the entire zooplanktonic community, the significance of the PP-mesozooplankton consumption relationship was higher for the three intervals of PP considered $(P<0.06$, for unproductive; $P$ $<0.05$ for moderately productive; and $P<0.0001$ for productive regions). Thus, other groups, apart from copepods, seem to be important drivers of the PP-grazing relationship, especially in unproductive areas. For the sake of speculation, if the grazing estimates reported in this study were only due to copepods or other organisms that cannot exploit picoplankton, the percentage of $>2 \mu \mathrm{m}$ PP removed by grazers would be 74,37 , and $15 \%$ in unproductive, moderately productive, and highly productive regions, respectively (assuming proportions of picoplankton to total production according to Agawin et al. 2000).

Duarte and Cebrián (1996) calculated that grazing removes, on average, $56.9 \%$ of oceanic PP and $40.6 \%$ of coastal marine PP. These estimates comprise grazing by both microheterotrophs (including protozoans and micrometazoans) and mesozooplankton. If moderately productive and unproductive areas are considered as representative of open ocean and highly productive areas represent coastal environments, mesozooplankton grazing on PP is one-half and one-quarter, respectively, of the total effect suggested by Duarte and Ce- 

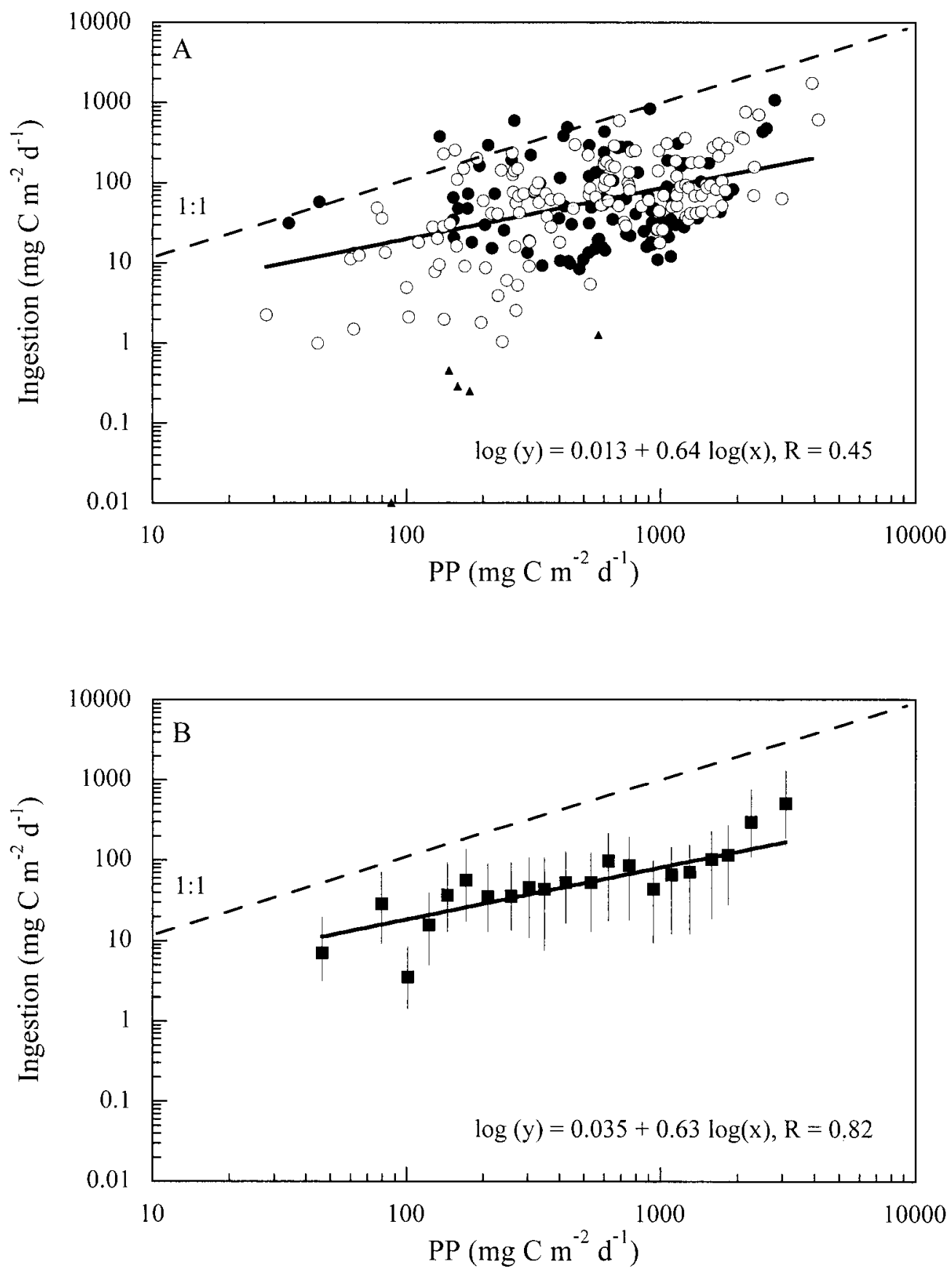

Fig. 1. (A) Phytoplankton biomass $\left(\mathrm{mg} \mathrm{C} \mathrm{m}^{-2}\right)$ consumed daily by mesozooplankton as a function of PP. Dark circles represent studies considering only copepods. Open circles represent studies considering the whole mesozooplanktonic community. Triangles fall outside the $1.5 \times$ interquartile range and represent outliers that were not included in the regression equation. Equation parameters: intercept $\mathrm{SE}=0.226$, slope $\mathrm{SE}=0.082$, residual mean square $=0.26, n=238, P<0.0001$. (B) Geometric means within increasing bins and their standard error (vertical bars). Bins were calculated by dividing log-transformed PP data into 25 equivalent intervals. To ensure the consistency of bins and to avoid presenting empty intervals, first and last bins are the combination of several intervals with and without data. The regression equation was weighted using the number of data in each bin. No significant differences were found between equations in Fig. 1A and B (ANCOVA). Equation parameters: intercept $\mathrm{SE}=0.283$, slope $\mathrm{SE}=0.103$, residual mean square $=0.41, n=21, P<$ 0.0001 . 


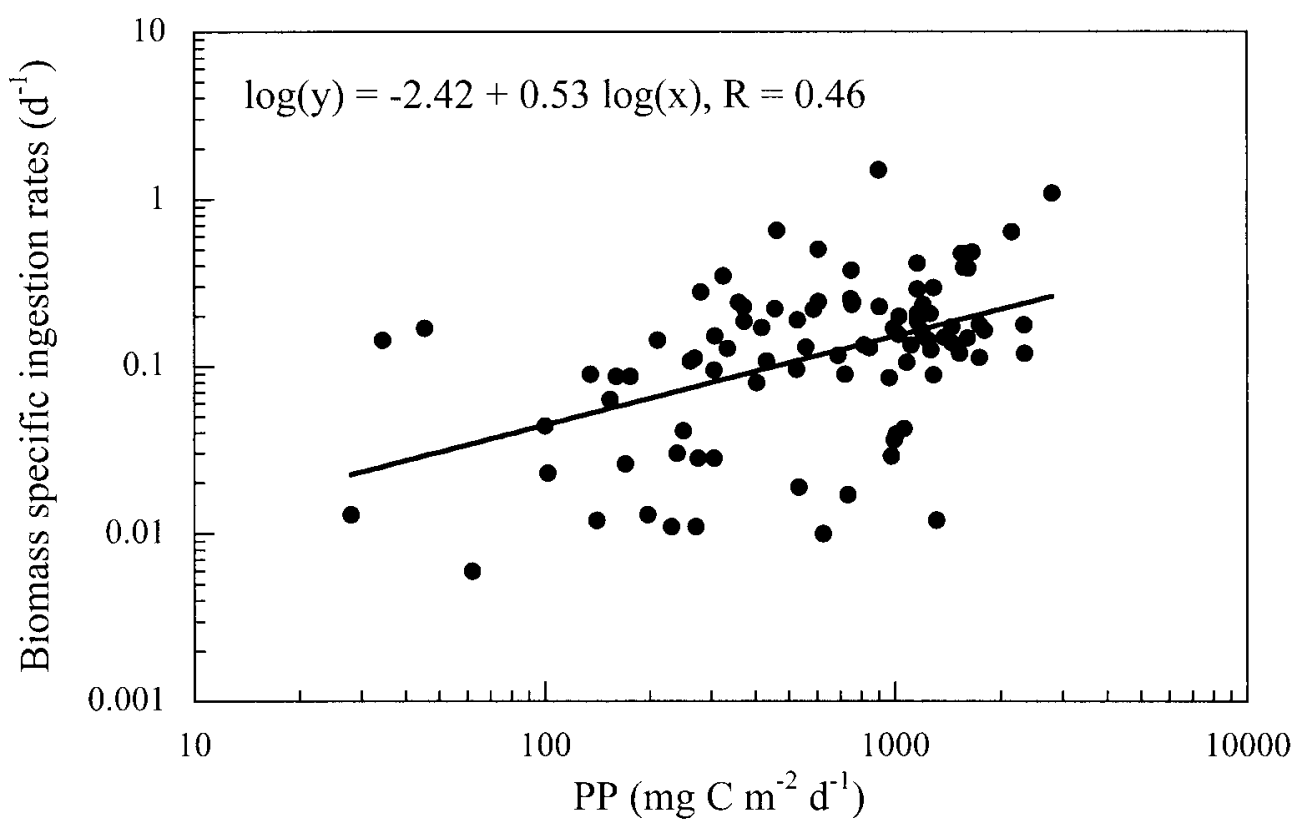

Fig. 2. Mesozooplankton biomass-specific ingestion rates as function of PP. Equation parameters: intercept $\mathrm{SE}=0.30$, slope $\mathrm{SE}=0.11$, residual mean square $=0.18, n=93, P<0.0001$.

brián (1996). Hence, the comparison of both data sets would lead to the conclusion that the grazing pressure of mesozooplankton on oceanic PP is comparable to that of microzooplankton, which are considered to be the main grazers in the unproductive ocean (Tsuda et al. 1989; Bradford-Grieve et al. 1998). Surprisingly, in productive systems, microzooplankton would exert a higher grazing pressure than mesozooplankton, traditionally considered the main consumers of PP in these systems. There are two main consequences of the relatively higher-than-expected grazing effect of microzooplankton on autotrophs of highly productive areas. First, the "classic" or "herbivorous" food web (diatoms-large copepods-fish) seems to have less importance than microbial food webs. Second, it has important implications for the downward export flux of organic matter. Because microplankton fecal pellets are smaller, and consequently easier to remineralize within the euphotic zone, the losses by sedimentation due to zooplankton compaction must be lower than expected. In any case, these losses will be insignificant compared to phytoplankton export flux by advection, flocculation, or aggregation (Baines et al. 1994; Wassmann 1998). These results suggest that the relative importance of micro- and mesozooplankton in the food dynamics of marine ecosystems, as well as the role of mesozooplankton grazing, must be reevaluated.

On a global scale, the equations obtained in Fig. 1 can be used to estimate the integrated autotrophic carbon ingested by mesozooplankton in the world oceans. The calculated carbon consumed in each biogeochemical province (sensu

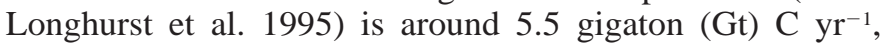
equivalent to about $12 \%$ of the oceanic PP. The carbon ingestion by metazoans is thus a significant loss factor for autotrophic carbon in the ocean, particularly in the oligotrophic provinces, which comprise $>2 / 3$ of the ocean area. Metazoan carbon ingestion does not necessarily represent a sink for organic carbon. Part of the ingested carbon is respired, the fraction ranging typically from 10 to 56\% (Bougis 1974; Kiørboe et al. 1985; Pagano et al. 1993). An average respiratory loss of $25 \%$ of the carbon ingested from primary production suggests a $\mathrm{CO}_{2}$ production from mesozooplankton

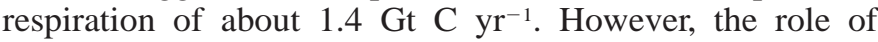
mesozooplankton as a $\mathrm{CO}_{2}$ source has been neglected in current debates about the metabolic balance of oceanic communities (e.g., del Giorgio and Cole 1997; Duarte and Agustí 1998; Williams 1998). Furthermore, the higher mesozooplankton grazing pressure on primary production in unproductive communities seems to be new evidence toward the dominance of heterotrophic processes, and the role of the unproductive ocean as a net heterotrophic system (e.g., del Giorgio and Cole 1997; Duarte and Agustí 1998).

Albert Calbet ${ }^{1}$

Institut de Ciències del Mar-CMIMA, CSIC

Departament de Biologia Marina i Oceanografia

Passeig Marítim de la Barceloneta, 37-49

08003 Barcelona, Catalunya, Spain

\section{References}

Agawin, N., C. M. Duarte, and S. Agustí. 2000. Nutrient and temperature control of the contribution of picoplankton to phytoplankton biomass and production. Limnol. Oceanogr. 45: 591-600.

\footnotetext{
${ }^{1}$ Corresponding author (acalbet@icm.csic.es).
}

Acknowledgments

The author is deeply grateful to C. M. Duarte, E. Saiz, M. Alcaraz, X. Irigoien, J. M. Gasol, and two anonymous reviewers for valuable comments and suggestions on earlier drafts of the manuscript. This work was supported by grant MAR98-0854. 
AlCARAZ, M. 1982. Zooplankton biomass and its relation to total particulate carbon and nitrogen of northwest Africa. Rap. P.-V. Réun. Cons. Int. Explor. Mer. 180: 270-273.

Arinardi, O. H., M. A. BAARs, AND S. S. Oosterhuis. 1990. Grazing in tropical copepods, measured by gut fluorescence, in relation to seasonal upwelling in the Banda Sea (Indonesia). Neth. J. Sea Res. 25: 545-560.

Atkinson, A., AND R. S. ShreEve. 1995. Response of the copepod community to a spring bloom in the Bellinghausen Sea. DeepSea Res. II 42: 1291-1311.

Azam, F., T. Fenchel, J. G. Field, J. S. Grey, L. A. Meyer-Reil, AND F. Thingstad. 1983. The ecological role of water-column microbes in the sea. Mar. Ecol. Prog. Ser. 10: 257-263.

BaArs, M. A., AND H. G. Fransz. 1984. Grazing pressure of copepods on the phytoplankton stock of the central North Sea. Neth. J. Sea Res. 18: 120-142.

Baines, S. B., L. M. PACE, And D. M. Karl. 1994. Why does the relationship between sinking flux and plankton primary production differ between lakes and oceans? Limnol. Oceanogr. 39: 213-226.

Barquero, S., J. A. Cabal, R. Anadón, E. Fernández, M. VarELA, AND A. BODE. 1998. Ingestion rates of phytoplankton by copepod size fractions on a bloom associated with an off-shelf front off NW Spain. J. Plankton Res. 20: 957-972.

Bougis, P. 1974. Ecologie du plancton marin. Masson et Cie.

Bradford-Grieve, J., R. Murdoch, M. JAmes, M. Oliver, AND J. MCLEOD. 1998. Mesozooplankton biomass, composition, and potential grazing pressure on phytoplankton during austral winter and spring 1993 in the subtropical convergence region near New Zealand. Deep-Sea Res. I 45: 1709-1737.

CAlbet, A., AND M. R. LANDRY. 1999. Mesozooplankton influences on the microbial food web: Direct and indirect trophic interactions in the oligotrophic open ocean. Limnol. Oceanogr. 44: $1370-1380$.

, — AND R. D. ScheInBerg. 2000. Copepod grazing in a subtropical bay: Species-specific responses to a midsummer increase in nanoplankton standing stock. Mar. Ecol. Prog. Ser. 193: 75-84.

$\longrightarrow,-$, AND S. NUNNERY. 2001. Bacteria-flagellate interactions in the microbial food web of the oligotrophic subtropical North Pacific. Aquat. Microb. Ecol. 23: 283-292.

Conover, R. J., AND P. MAYZAUd. 1984. Utilization of phytoplankton during the spring bloom in Nova Scotia inlet. Can. J. Fish. Aquat. Sci. 41: 233-244.

DagG, J. M., J. Vidal, T. E. Whitledge, R. L. Iverson, And J. J. GoERING. 1982. The feeding, respiration, and excretion of zooplankton in the Bering Sea during a spring bloom. Deep-Sea Res. I 29: 45-63.

Dam, A. G., C. A Miller, And S. H. JónAsdóttir. 1993. The trophic role of mesozooplankton at $47 \mathrm{~N}, 20 \mathrm{~W}$ during the North Atlantic bloom experiment. Deep-Sea Res. II 40: 197-212.

DAm, H. G., AND W. T. Peterson. 1988. The effect of temperature on the gut clearance rate constant of planktonic copepods. J. Exp. Mar. Biol. Ecol. 123: 1-14.

- X. Zhang, M. Butler, And M. R. Roman. 1995. Mesozooplankton grazing and metabolism at the equator in the central Pacific: Implications for carbon and nitrogen fluxes. DeepSea Res. II 42: 735-756.

DEl Giorgio, P. A., AND J. J. Cole. 1997. Photosynthesis or planktonic respiration? A reply. Nature 388: 132-133.

Duarte, C. M., And S. Agustí. 1998. The $\mathrm{CO}_{2}$ balance of unproductive aquatic ecosystems. Science 281: 234-236.

— AND J. CEBRIÁN. 1996. The fate of marine autotrophic production. Limnol. Oceanogr. 41: 1758-1766.

Dubischar, C. D., AND U. V. BATHMANN. 1997. Grazing impact of copepods and salps on phytoplankton in the Atlantic sector of the Southern Ocean. Deep-Sea Res. II 44: 415-433.

Fessenden, L., And T. J. Cowles. 1994. Copepod predation on phagotrophic ciliates in Oregon coastal waters. Mar. Ecol. Prog. Ser. 107: 103-111.

Fortier, L., J. Le Fevre, AND L. Legendre. 1994. Export of biogenic carbon to fish and to the deep ocean: The role of large plankton microphages. J. Plankton Res. 16: 809-839.

Froneman, P. W., E. A. Pakhomov, R. Perissinotto, R. K. Laubscher, And C. D. MCQuaid. 1997. Dynamics of the plankton communities of the Lazarev Sea (Southern Ocean) during seasonal ice melt. Mar. Ecol. Prog. Ser. 149: 201-214. $\longrightarrow,-, \longrightarrow$, AND C. D. MCQUAID. 2000. Zooplankton structure and grazing in the Atlantic sector of the Southern Ocean in late austral summer 1993-part 2. Biochemical zonation. Deep Sea Res. I 47: 1687-1702.

Gasol, J. M., P. A. Del Giorgio, and C. M. Duarte. 1997. Biomass distribution in marine planktonic communities. Limnol. Oceanogr. 42: 1353-1363.

González, H. E., M. Sobarzo, D. Figueroa, and E. M. Nothig. 2000. Composition, biomass and potential grazing impact of the crustacean and pelagic tunicates in the northern Humboldt Current area off Chile: Differences between El Niño and nonEl Niño years. Mar. Ecol. Prog. Ser. 195: 201-220.

Gorsky, G., AND R. FenauX. 1998. The role of Appendicularia in marine food webs, p. 161-170. In Q. Bone [ed.], The biology of pelagic tunicates. Oxford University Press.

Gowen, R. J., G. Mccullough, G. S. Kleppel, L. Houchin, And P. ElLiotT. 1999. Are copepods important grazers of the spring phytoplankton bloom in the western Irish Sea? J. Plankton Res. 21: 465-483.

Hirst, A. G., AND R. S. LAmpitT. 1998. Towards a global model of in situ weight-specific growth in marine planktonic copepods. Mar. Biol. 132: 247-257.

Huntley, M. E., AND M. D. G. Lopez. 1992. Temperature dependent production of marine copepods: A global synthesis. Am. Nat. 140: 201-242.

Huskin, I. 2001. Ingestión herbívora de copépodos en el Océano Atlántico. Ph.D. thesis, University of Oviedo.

KiøRboe, T., And P. Tiselius. 1987. Gut clearance and pigment destruction in a herbivorous copepod Acartia tonsa and the determination of in situ grazing rates. J. Plankton Res. 9: 525-534. , F. Mohlenberg, And K. Hamburger. 1985. Bioenergetics of the planktonic copepod Acartia tonsa: Relation between feeding, egg production and respiration and composition of specific dynamic action. Mar. Ecol. Prog. Ser. 26: 85-97.

KNAUER, G. A. 1993. Productivity and new production of the oceanic system, p. 211-231. In R. Wollast [ed.], Interactions of C, $\mathrm{N}, \mathrm{P}$ and $\mathrm{S}$ biogeochemical cycles and global change. SpringerVerlag.

Landry, M. R., C. J. Lorenzen, And W. K. Peterson. 1994. Mesozooplankton grazing in the Southern California Bight. 2. Grazing impact and particulate flux. Mar. Ecol. Prog. Ser. 115: 73-85.

Longhurst, A., T. Sathyendranath, T. Platt, and C. CaverHILL. 1995. An estimate of global primary production in the ocean from satellite radiometer data. J. Plankton Res. 17: $1245-1271$.

Mayzaud, P., AND S. Razouls. 1992. Degradation of gut pigment during feeding by a subantarctic copepod: Importance of feeding history and digestive acclimation. Limnol. Oceanogr. 37: 393-404.

Morales, C. E., A. Bedo, R. P. Harris, and P. R. G. Tranter. 1991. Grazing of copepod assemblages in the north-east Atlantic: The importance of the small size fraction. J. Plankton Res. 13: 455-472. 
NiElsen, T. G., AND B. HANSEN. 1995. Plankton community structure and carbon cycling on the western coast of Greenland during and after the sedimentation of a diatom bloom. Mar. Ecol. Prog. Ser. 125: 239-257.

Pace, M. L., J. J. Cole, and S. R. Carpenter. 1998. Trophic cascades and compensation: Differential responses of microzooplankton in whole-lake experiments. Ecology 79: 138-152.

Pagano, M., R. Gaudy, D. Thibault, and F. Lochet. 1993. Vertical migrations and feeding rhythms of mesozooplanktonic organisms in the Rhone River plume area (North-West Mediterranean Sea). Estuar. Coast. Shelf Sci. 37: 251-269.

PAKhomov, E. A., AND R. PerissinotTo. 1997. Mesozooplankton community structure and grazing impact in the region of the Subtropical Convergence south of Africa. J. Plankton Res. 19: 675-691.

- H. M. Verheye, A. Atkinson, R. K. Laubscher, And J. TAUNTON-Clark. 1997. Structure and grazing impact of the mesozooplankton community during late summer 1994 near South Georgia, Antarctica. Polar Biol. 18: 180-192.

Roman, M. R., AND A. L. Gauzens. 1997. Copepod grazing in the equatorial Pacific. Limnol. Oceanogr. 42: 623-634.

, H. G. DAM, A. L. GauZENS, AND J. M. NAPP. 1993. Zooplankton biomass and grazing at the JGOFS Sargasso Sea time series station. Deep-Sea Res. I 40: 883-901.

Sautour, B., F. Artigas, A. Herbland, and P. Laborde. 1996. Zooplankton grazing impact in the plume of dilution of the Gironde Estuary (France) prior to the spring bloom. J. Plankton Res. 18: 835-853.

- D. Delmas, A. Herbland, and P. Laborde. 2000. Grazing impact of micro- and mesozooplankton during a spring situation in coastal waters off the Gironde estuary. J. Plankton Res. 22: 531-552.

Sherr, B. F., E. B. Sherr, AND F. RAssoulzadegan. 1988. Rates of digestion of bacteria by marine phagotrophic protozoa: Temperature dependence. Appl. Environ. Microbiol. 54: 10911095.

STRAILE, D. 1997. Gross growth efficiencies of protozoan and metazoan zooplankton and their dependence on food concentration, predator-prey weight ratio, and taxonomic group. Limnol. Oceanogr. 42: 1375-1385.

Tiselius, P. 1988. Effects of diurnal feeding rhythms, species composition and vertical migration on the grazing impact of calanoid copepods in the Skagerrak and Kattegat. Ophelia 28: $215-230$.

1989. Contribution of aloricate ciliates to the diet of Acartia clausi and Centropages hamatus in coastal waters. Mar. Ecol. Prog. Ser. 56: 49-56.

TsudA, A., K. Furuya, AND T. Nemoto. 1989. Feeding of microand macrozooplankton at the subsurface chlorophyll maximum in the subtropical North Pacific. J. Exp. Mar. Biol. Ecol. 132: $41-52$.

Ward, P., A. Atkinson, A. W. A. Murray, A. G. Wood, R. WilLIAMS, AND S. A. Poulet. 1995. The summer zooplankton community at South Georgia: Biomass, vertical migration and grazing. Polar Biol. 15: 195-208.

WassmanN, P. 1998. Retention versus export food chains: Processes controlling sinking loss from marine pelagic systems. Hydrobiologia 363: 29-57.

WiLliams, P. J. LBE. 1998. The balance of plankton respiration and photosynthesis in the open ocean. Nature 394: 55-57.

Zhang, X., H. G Dam., J. R. White, and M. R. Roman. 1995. Latitudinal variations in mesozooplankton grazing and metabolism in the central tropical Pacific during the U.S. JGOFS EqPac study. Deep Sea Res. II 42: 695-714.

Received: 22 November 2000 Accepted: 15 May 2001 Amended: 7 June 2001 